\title{
Erratum to: The number and nature of emergency department encounters in patients with deep brain stimulators
}

\author{
Andrew S. Resnick - Kelly D. Foote $\cdot$ Ramon L. Rodriguez $\cdot$ Irene A. Malaty \\ Joel L. Moll - Donna L. Carden · Nolie E. Krock - Matthew M. Medley • \\ Adam Burdick • Ihtsham U. Haq • Michael S. Okun
}

Published online: 14 November 2009

(C) Springer-Verlag 2009

Erratum to: J Neurol

DOI 10.1007/s00415-009-5343-8

Due to an unfortunate error Table 8 was published with errors. The correct Table 8 is printed here.

The online version of the original article can be found under doi:10.1007/s00415-009-5343-8.

\footnotetext{
A. S. Resnick $(\varangle)$ - R. L. Rodriguez · I. A. Malaty ·

N. E. Krock · M. M. Medley · I. U. Haq · M. S. Okun

Department of Neurology, University of Florida,

Gainesville, USA

e-mail: aresnick@ufl.edu

K. D. Foote · A. Burdick

Department of Neurosurgery, University of Florida,

Gainesville, USA

J. L. Moll · D. L. Carden

Department of Emergency Medicine, University of Florida,

Gainesville, USA
} 


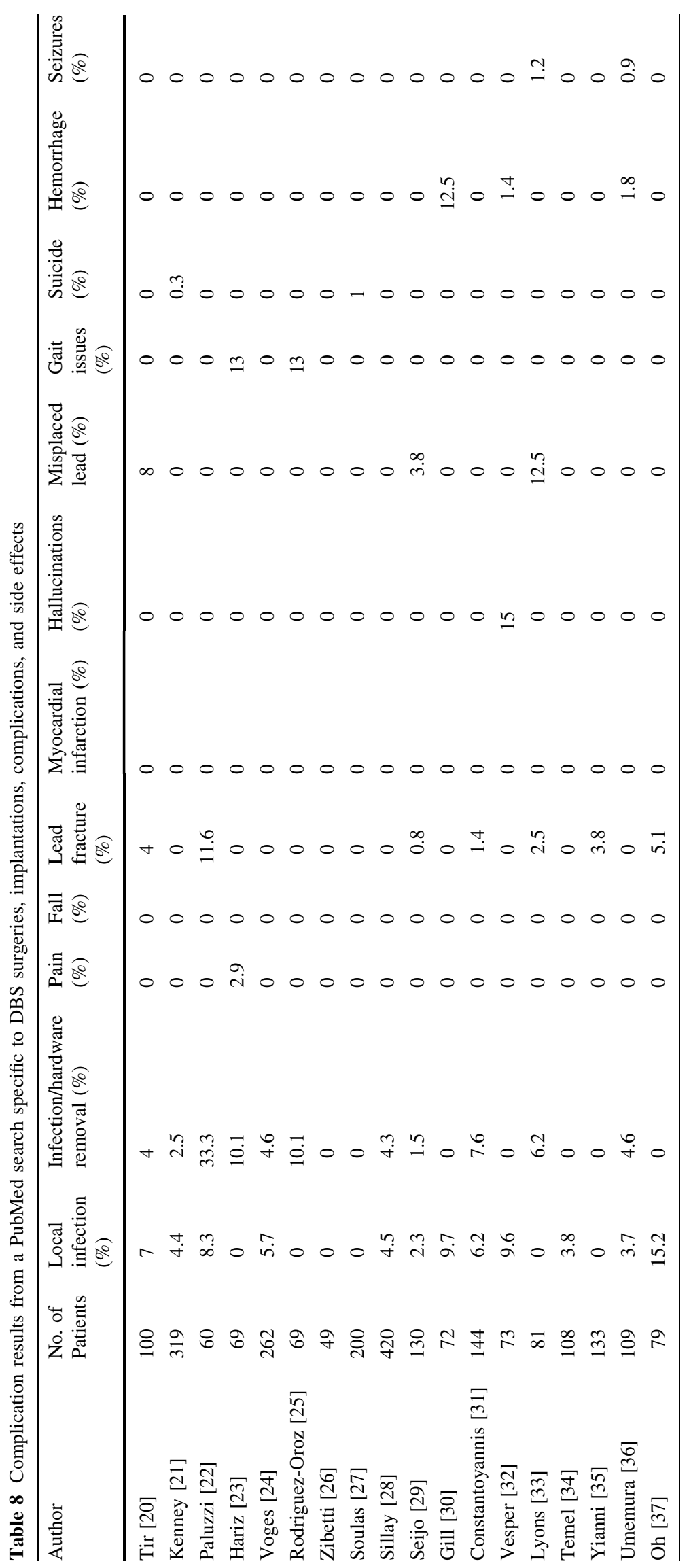

